\title{
EVALUATION OF THE DEPOSITION OF NANOPARTICLES IN THE HUMAN RESPIRATORY TRACT FROM THE BURNING OF DIESEL I BIODIESEL / ADDITIVE
}

\author{
Clara Rodrigues Pereira ${ }^{a}$, Pedro Bancillon Ventin Muniz ${ }^{a, b}$, Katheelin Rios Santa \\ Rosa ${ }^{a}$, Ednildo Andrade Torres ${ }^{b}$, Lílian Lefol Nani Guarieiro ${ }^{a}$ \\ a Centro Universitario Senai Cimatec, Brazil \\ ${ }^{b}$ PEI/UFBA, Brazil
}

\begin{abstract}
The aim of this study was to evaluate the deposition in the respiratory tract of nanoparticles (11.5nm to $365.2 \mathrm{~nm}$ ) from the burning of diesel, biodiesel and additives. The studied fuels were pure diesel (D), binary mixture of pure diesel with $11 \%$ biodiesel (B11) and ternary mixture of pure diesel, with $11 \%$ biodiesel and with the biocatalyst Xmile (B11X). The impact of nanoparticles on health was assessed using the MPPD lung model. From the tests, the burning of the studied fuels showed concentration of number of particles in the accumulation mode $(50 \mathrm{~nm}$ to $120 \mathrm{~nm})$. When comparing fuels, it was clear that B11 emits more particles and has a greater deposition capacity in the lung. B11X has been shown to be efficient in reducing pollutant emissions as well as impacting human health.
\end{abstract}

Keywords: Deposition; respiratory tract; biodiesel; MPPD.

\section{AVALIAÇÃO DA DEPOSIÇÃO DE NANOPARTÍCULAS NO TRATO RESPIRATÓRIO HUMANO ORIUNDAS DA QUEIMA DE DIESEL/BIODIESEL/ADITIVO}

\begin{abstract}
Resumo:
O objetivo deste estudo foi avaliar a deposição de nanopartículas (11,5nm a 365,2nm) no trato respiratório oriundas da queima de diesel, biodiesel e aditivo. Os combustíveis estudados foram o diesel puro (D), mistura binária de diesel puro com $11 \%$ de biodiesel (B11) e mistura ternária de diesel puro, com $11 \%$ de biodiesel e com o biocatalisador Xmile (B11X). O impacto das nanopartículas na saúde, foi avaliado através do modelo pulmonar MPPD. A partir dos testes, a queima dos combustíveis estudados apresentou concentração de número de partículas na moda de acumulação (50nm a 120nm). Ao comparar os combustíveis foi notório que o B11 emite mais partículas e possui maior capacidade de deposição no pulmão. O B11X, mostrou-se eficiente na redução de emissão de poluentes assim como no impacto na saúde humana.
\end{abstract}

Palavras-chave: Deposição; trato respiratório; biodiesel; MPPD. 


\section{INTRODUCTION}

Diesel engines play an important role in the world economic scenario, for have a higher energy productivity, higher power and a considerable durability [1]. These particularities are associated with many applications such as transportation, pumps and electricity generators. Despite having such applicability, diesel engines are responsible for the growing of pollutants in the atmosphere, such as: total hydrocarbons, nitrogen oxides, carbon monoxide and particulate matter (PM) [2].

Atmospheric particles material (PM) consists of heterogeneous mixtures of solids and liquid particles suspended in the air that vary in size and chemical composition, such as: nitrates; sulfates; elemental and organic carbon; organic compounds (for example, polycyclic aromatic hydrocarbons); biological compounds (for example, endotoxin, cell fragments, viruses); and metals (for example, iron, copper, nickel, zinc and vanadium) [3,4].

The PM can be classified according to its transport capacity in the air, which is associated with particle diameter sizes. It can be categorized as: Coarse ( $\left.\mathrm{PM}_{10}\right)$, Fine $\left(\mathrm{PM}_{2.5}\right)$ and ultrafine $\left(\mathrm{PM}_{0.1}\right)$ [ 5]. The $\mathrm{PM}_{10}$ has an aerodynamic diameter smaller than 10 micrometers $(\mu \mathrm{m}) ; \mathrm{PM}_{2.5}$ has an aerodynamic diameter smaller than $2.5 \mu \mathrm{m}$ and PMo.1 has an aerodynamic diameter less than $0.1 \mu \mathrm{m}$ [5]. The particulate matter emitted by diesel engines consists of a predominance of fine particles $\left(\mathrm{PM}_{2.5}\right)$ and ultrafine particles (PM0.1) [6].

In order to improve the engine performance and regulate the emission of pollutants, additives, also called oxygenated fuels, are added to diesel [7]. Oxygenated additives mixed with diesel fuels promote combustion and octane processes without emitting a high amount of pollutants to the atmosphere [8]. Generally, the most applied additives are alcohols (butanol, propanol, methanol and ethanol), ethers (diethyl ether, tert-butyl methyl ether) and esters (acetoacetic esters, dicarboxylic acid esters and methyl esters) [8]. The application of these additives in diesel, inhibits the formation of particles considering the existence of less unsaturated micro molecules, such as $\mathrm{C}_{2} \mathrm{H}_{2}$, that contribute for the reduction of PM emissions in the combustion process [9].

The particulate matter from diesel engines not only are responsible for a huge impact on atmosphere, but can result in cardiovascular, respiratory and carcinogenic diseases, considering that the inhalation can be a means of contact between the human organism and the PM [7]. This interaction happens in a way that the smaller the particle, higher is the capacity to absorb organic and inorganic compounds in the respiratory tract [3]. The fine particles $\left(\mathrm{PM}_{2.5}\right)$, for example, when inhaled run through the bronchioles and alveolus (where gas exchange occurs) inducing carcinogenic (lung cancer symptoms) and mutagenic (breaks and changes in the genetic chain) effects [3]. Therefore, the use of additives in diesel cycle engines is not only intended to reduce the emission of atmospheric pollutants, but also to reduce the impact that particulate matter can cause on the human respiratory tract.

It is necessary to highlight the current scenario of COVID - 19 which is worrying, especially in countries where the level of pollution and the incidence of deaths resulting from the emission of PM are quite high. These factors can lead to more serious symptoms with the action of the virus that has been decimating. However, when introducing the measures imposed by the quarantine, it was possible to visualize a scenario that reduces emissions from transport and industries, enabling an improvement in air quality [10]. As an example, there is a study realized in India, in March 2020, with the objective of measuring the incidence of pollutants in the 
atmosphere after the measures imposed to contain the spread of COVID-19 [11]. The results demonstrated a significant improvement in air quality in a period when there is no intense car flow in cities due to the measures implemented during the COVID-19 pandemic [10].

The objective of this work was to evaluate the deposition of nanoparticles $(11.5 \mathrm{~nm}$ to $365.2 \mathrm{~nm}$ ) from the burning of diesel, biodiesel and additives in the respiratory tract

\section{METHODOLOGY}

The present study presents the methodological flow present in Figure 1, which will be detailed below.

Figure 1. Flowchart of the methodology applied in the study

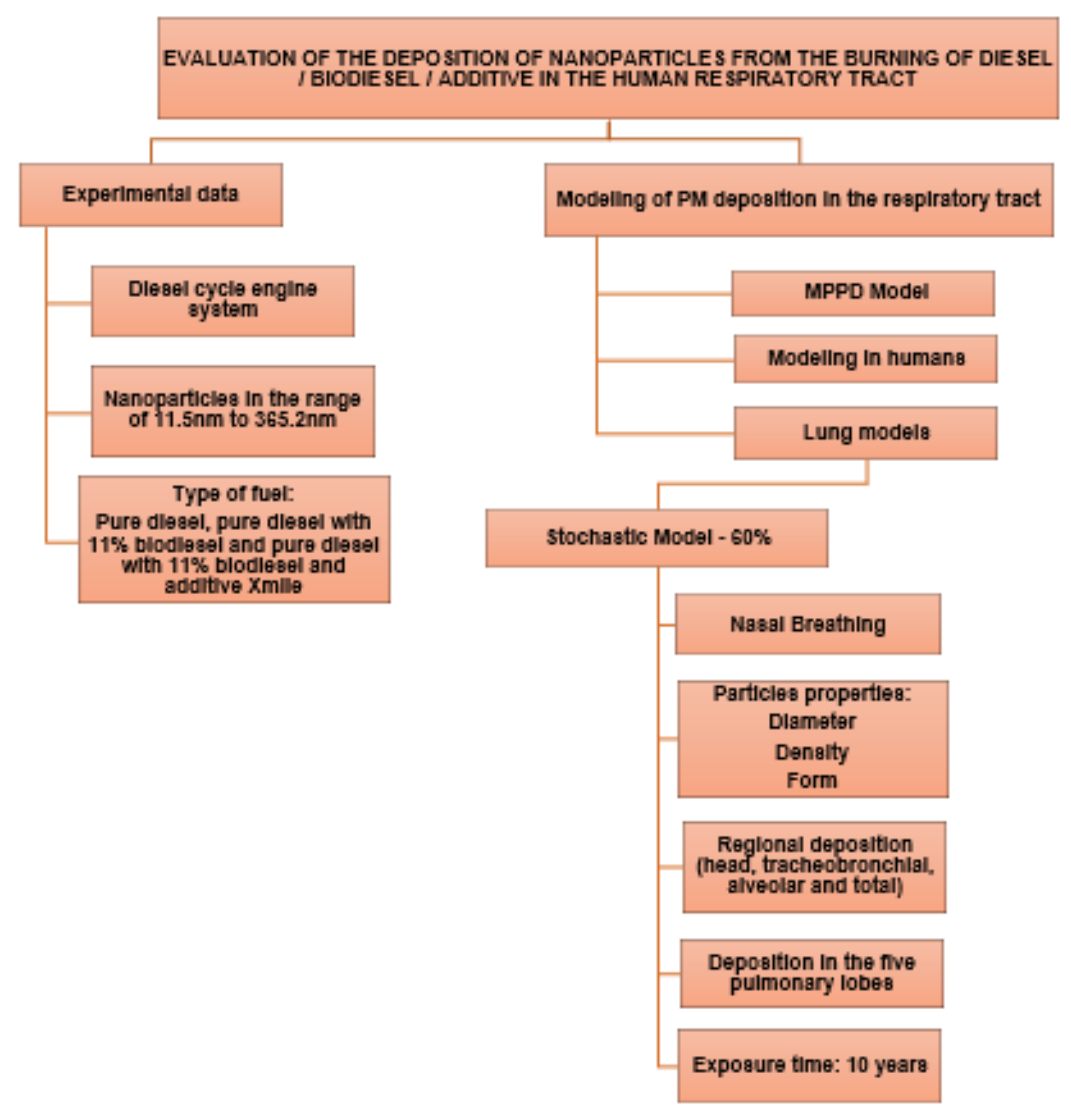

In the development of the experimental stage of the study, three fuels were used: pure diesel, B11 (binary mixture of pure diesel with $11 \%$ biodiesel) and B11X (ternary mixture of pure diesel, with $11 \%$ biodiesel and with the biocatalyst Xmile). An Agrale diesel engine, model N-790, speed $1700 \mathrm{rpm}$ was used, coupled to a hydraulic dynamometer (Schenck) with a maximum rotation of $10,000 \mathrm{rpm}$. Integrated to this system, a partial dilution tunnel was used to sample the particulate matter with a partial exhaust dilution rate of 24 .

A Nanoscan SMPS 3910 particle counter was coupled to the exhaust system in order to measure the concentration and distribution of the particulate material size $(11.5 \mathrm{~nm}$ to $365.2 \mathrm{~nm})$ according to the variation of its concentration, in a 10 minutes time range with three replicates for each fuel (D, B11 and B11X). 
In order to evaluate how the variation of particle sizes from the vehicle emission behave in the respiratory tract, the MPPD software (Multiple-path Particle Dosimetry Model) version 3.04 was used applying the experimental data of this study. It is based on a lung geometry model, by Yeh and Schum (1980) that simulates the deposition of particulate material in different regions from the anatomy of the species studied by adopting a dichotomous branch in the airway structure [11]. It consists of simple and multiple path methods in order to track the air flow and calculate the aerosol deposition in the lungs.

The single path method calculates deposition in a typical path by airway generation, while the multipath method calculates particle deposition in all airways in the lungs [12]. This model provides the study of regional deposition, extra thoracic, tracheobronchial and alveolar regions, where morphometric options are available to idealize the lung (Figure 3). Data such as PM properties and exposure conditions must be provided by standards or values specified by the user, where the deposition fraction can be estimated for particles with a size range between $1 \mathrm{~nm}$ and $100 \mu \mathrm{m}$ [12].

The model chosen in this study was the stochastic model that aims to calculate the deposition of PM in the lung in certain locations of the human respiratory tract, such as: regional (head, tracheobronchial, alveolar and total) and lobular (in the five pulmonary lobes) [12]. This model provides an estimate of the variability of the lung dose received by humans, generating more realistic deposition results.

Modeling in MPPD occurs according to the input data steps, essential to measure the level of PM concentration in the lung (Figure 2).

Figure 2. Flow of MPPD modeling

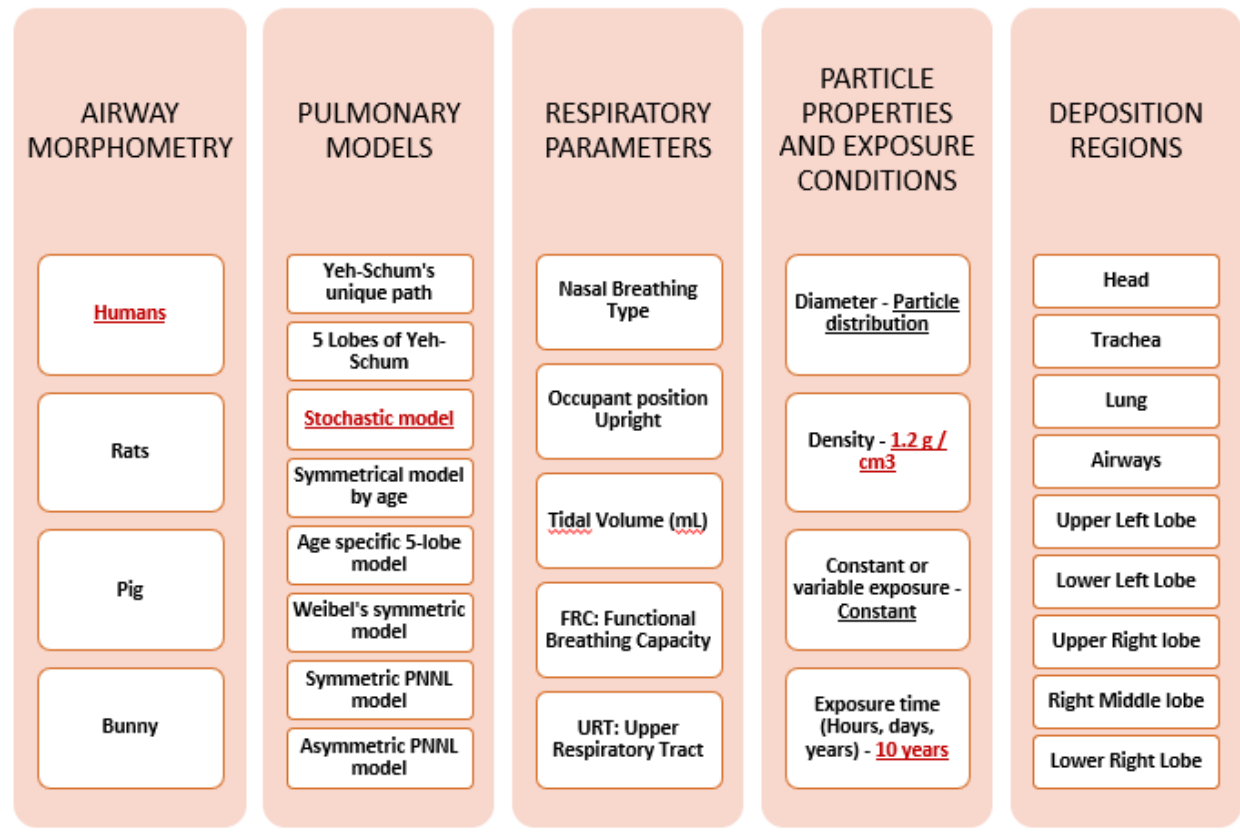

\section{RESULTS AND DISCUSSION}

The results obtained from the experimental tests showed that, the emissions of particulate material for the three fuels tested presented accumulation mode concentrations (50 $\mathrm{nm}$ to $160 \mathrm{~nm}$ ) (Figure 3).

Figure 3. Distribution of the number and size of fuel particles D, B11 and B11X. 


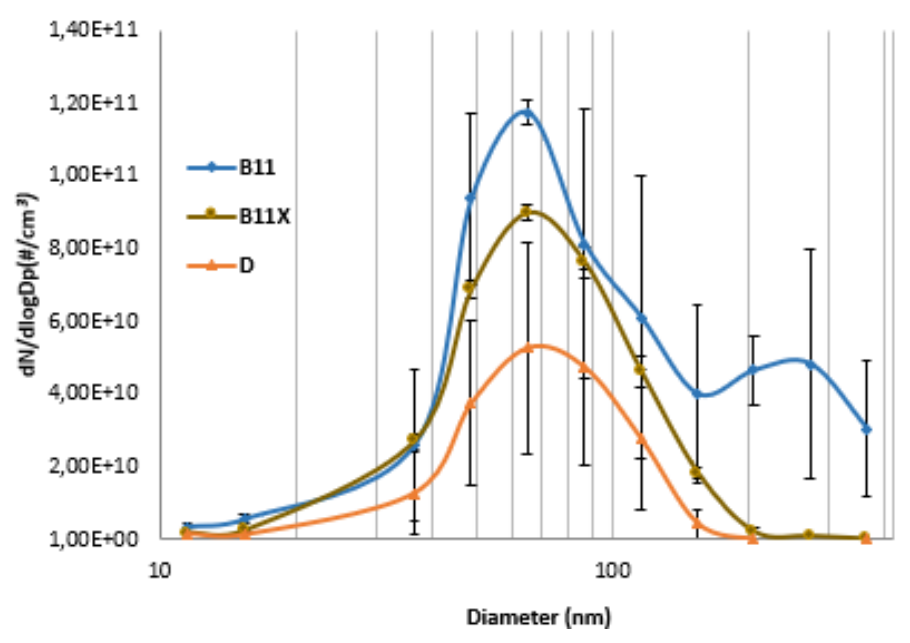

According to the literature, particles emitted by diesel engines are in the accumulation mode, in the range of $50 \mathrm{~nm}$ to $200 \mathrm{~nm}$ [13]. It means that the results obtained were satisfactory. It is also possible to observe that in a large part of the graph the error bars overlap, emphasizing that the three fuels have a statistically similar size and number of particles distribution, however, in the size range from $50 \mathrm{~nm}$ to $160 \mathrm{~nm}$ a difference in this distribution can be observed. It is worth mentioning that the addition of biodiesel promotes the reduction of the total mass of PM, however when compared to pure diesel it emits more ultrafine particles which are more harmful to health [13].

Therefore, the diameters that are included on the accumulation mode of the graphic obtained (50 nm to $160 \mathrm{~nm}$ ), were used as input data in the MPPD. The main goal of this simulation was to evaluate the impact of PM on the human respiratory tract.

Considering that the B11 fuel had the highest concentrations of PM emission, figure 4 shows the deposition of PM for the entire lung and for the 5 pulmonary lobes (left upper - LU; left lower - LL; right upper - RU; right middle - RM and right lower $\mathrm{RL})$.

Figure 4. Fractional deposition of MP in the airways in the lung lobes for the B11 fuel.

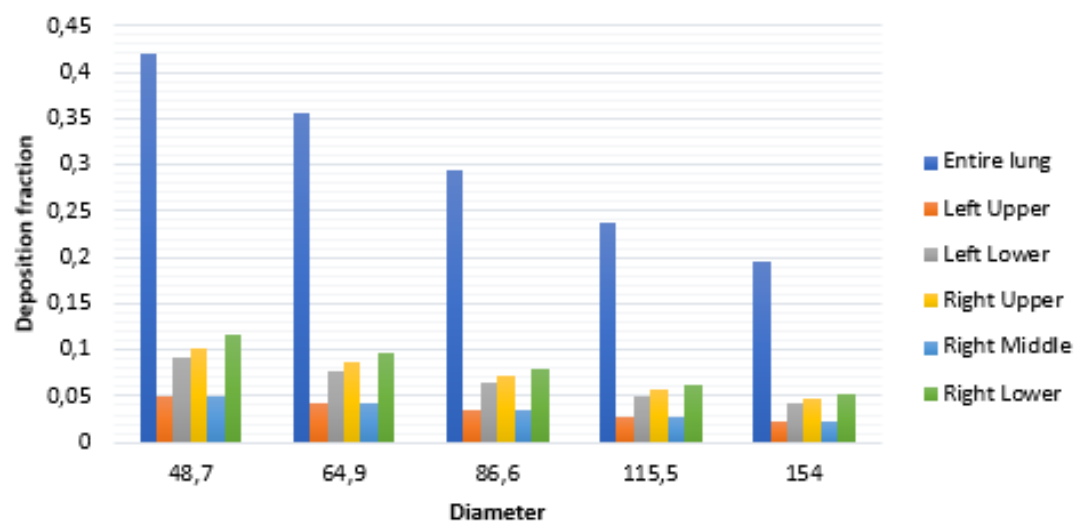

Figure 4 shows that the smaller the diameter, the greater is the deposition fraction in the lung. It is also worth mentioning that in the right lower lobe is where occurs more accumulation of particles while in the left upper lobe and right middle, the deposition of particles is lower.

To prove this, figure 5 represents the deposition fraction for the different generations or regions (from 0 to 23 ) that are part of the human respiratory tract. It also 
shows that the smaller the diameter, the greater the particle penetration capacity in the different regions of the respiratory tract.

Figure 5. Fractional deposition of B11 fuel particles by generation number for each aerodynamic particle diameter.

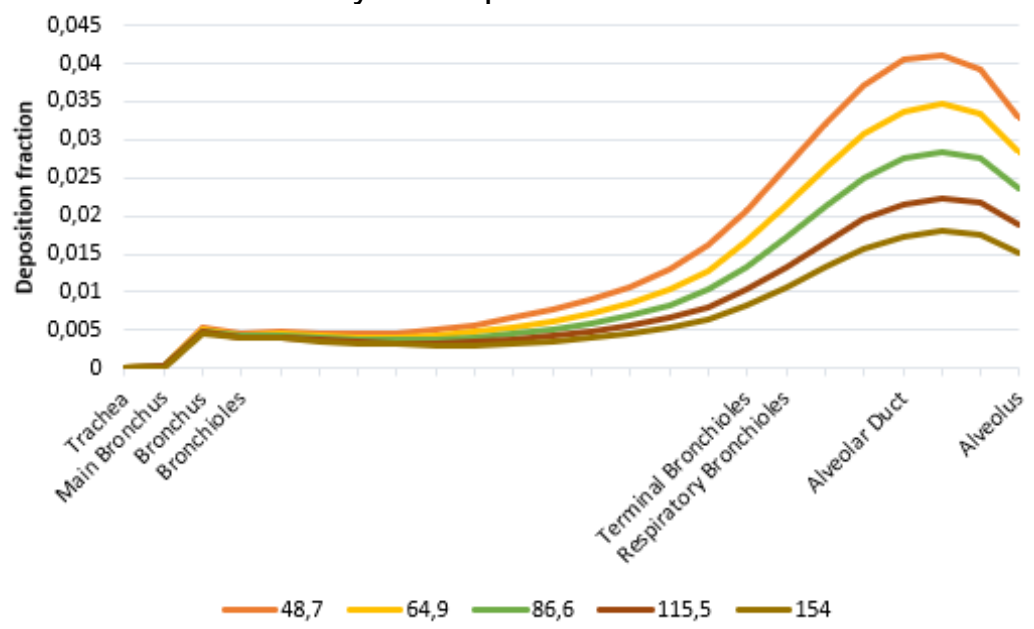

In order to measure the impact of PM on the respiratory tract, the following figures show the variation in the number of particles per alveolus, in the entire lung and in each lobe, for the three fuels studied.

Figure 7. Deposition fraction of the number of particles per well for the B11, B11X and D.

7a) Entire Lung, 7b) Left upper, 7c) Left lower, 7d) Right upper, 7e) Right middle and 7e) Right lower

a)
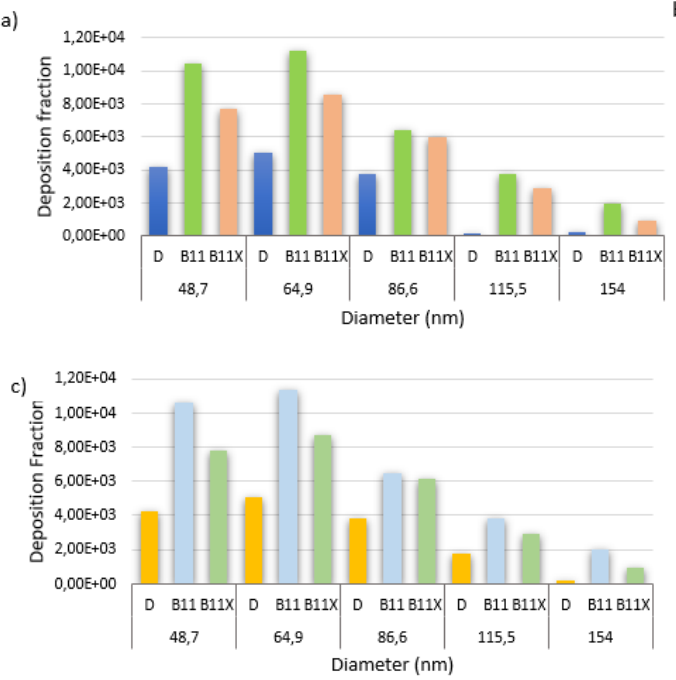

e)

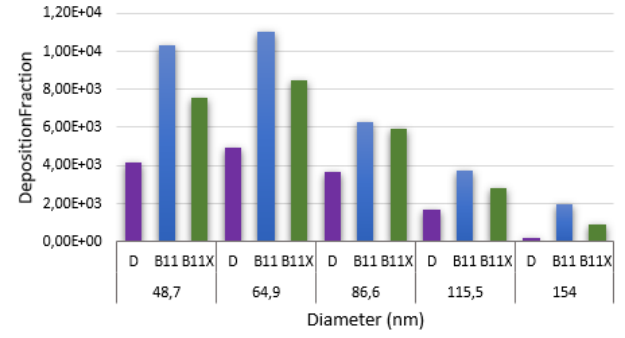

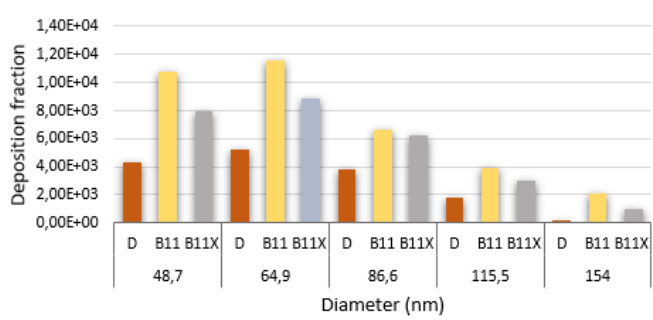

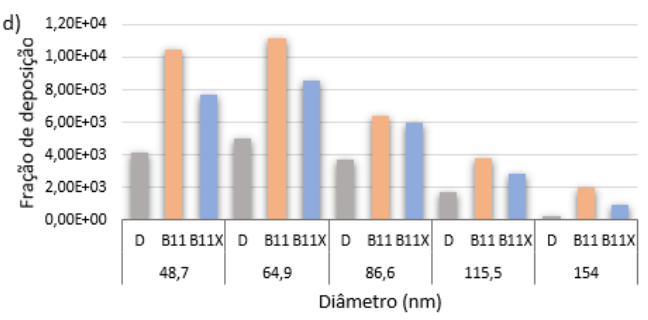

f)

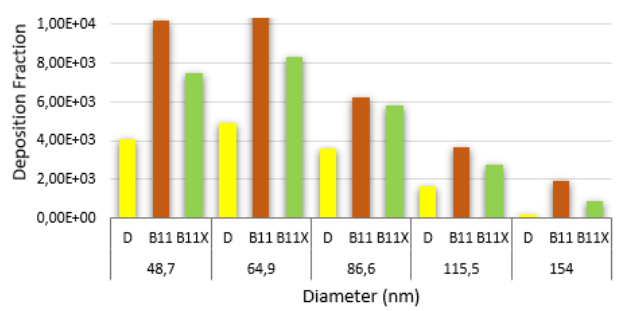


The figures showed that the numerical deposition per alveolus was higher for B11, especially for the diameter 64.9 , which corresponds to the peak of the PM emission graph, for the whole lung and for the 5 pulmonary lobes. The behavior of $\mathrm{B} 11 \mathrm{X}$ and $\mathrm{D}$ also corresponds to the MP emission graph of the diesel cycle engine, in which the deposition of particles by alveolus is greater in B11X than in D for all pulmonary regions. It is also important to mention that the deposition flow by size is the same, the smaller the diameter the greater the deposition fraction in the respiratory tract.

The simulation considered the following scenario of exposure to pollutants: the individual at the bus stop waiting for 1 hour a day, for 7 days a week, for 10 years. The sizes $64,9 \mathrm{~nm}$ and 86,6 were chosen to show how this type of exposure occurs, considering the B11 fuel (Figure 8). The exposure to particulate material increases over the years, noting that for the two diameters chosen, the level of exposure is almost the same.

Figure 8. Alveolar deposition over 10 years for particles with $64.9 \mathrm{~nm}$ and $86.6 \mathrm{~nm}$ in diameter for the B11 fuel

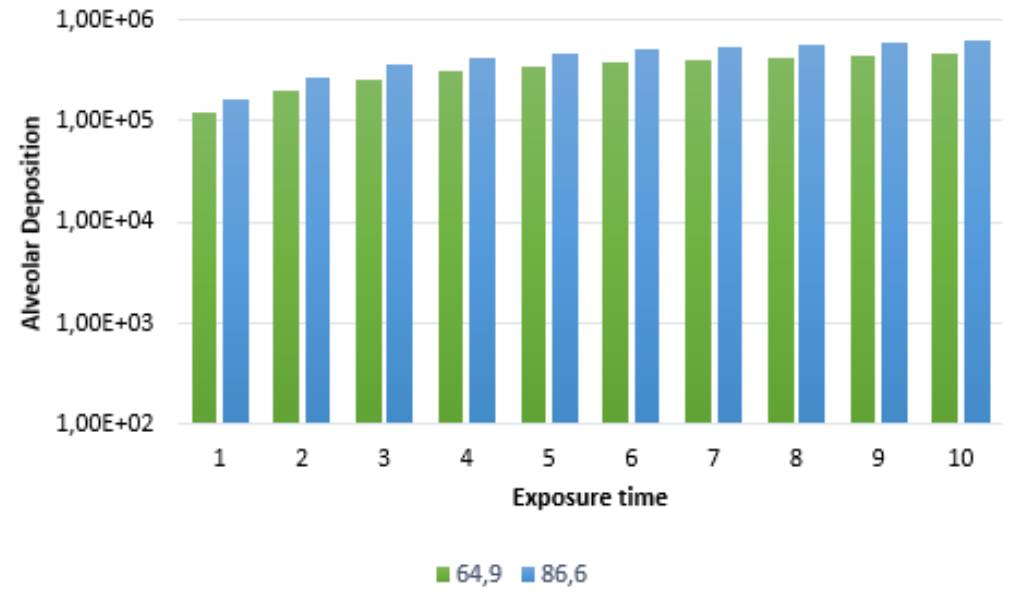

\section{CONCLUSION}

This work focused on the evaluation of the deposition of nanoparticles $(11.5 \mathrm{~nm}$ to $365.2 \mathrm{~nm}$ ) for pure diesel, the B11 fuel and the B11X fuel. It was possible to conclude that B11 even though promotes the reduction of the total PM mass emits more ultrafine particles in comparison to pure diesel. The addition of the additive Xmile proved to be efficient because it contributed to reduce particulate emissions, especially the ultrafine ones.

This was also observed in the analysis of the impact of particulate emissions from these fuels studied, on the respiratory tract. As it emits more small particles, the B11 fuel was the one with the greatest capacity for depositing particles in the pulmonary regions, proving that the smaller they are, more is the chance of penetrating the lung, especially the alveolus. On the other hand, the addition of Xmile additive not only promotes the reduction of particle emissions, but also contributed to less impact on the human respiratory system. 


\section{REFERENCES}

${ }^{1}$ KHAN, Muhammad Saad et al. Role of Oxygenated Additives for Diesel Fuel Blend "A Short Review". Journal of Applied Sciences, v. 15, n. 4, p. 619-625, 2015.

${ }^{2}$ FAYAD, Mohammed A.; TSOLAKIS, Athanasios; MARTOS, Francisco J. Influence of alternative fuels on combustion and characteristics of particulate matter morphology in a compression ignition diesel engine. Renewable Energy, v. 149, p. 962-969, 2020.

${ }^{3} \mathrm{KIM}$, Ki-Hyun; KABIR, Ehsanul; KABIR, Shamin. A review on the human health impact of airborne particulate matter. Environment international, v. 74, p. 136-143, 2015.

${ }^{4} \mathrm{ALI}$, Muhammad Ubaid et al. A systematic review on global pollution status of particulate matter-associated potential toxic elements and health perspectives in urban environment. Environmental geochemistry and health, p. 1-32, 2018.

${ }^{5}$ SCAFATI, Ferdinando Taglialatela et al. Modeling of Particle Size Distribution at the Exhaust of Internal Combustion Engines. In: Nonlinear Systems and Circuits in Internal Combustion Engines. Springer, Cham, 2018. p. 33-46.

${ }^{6}$ COLASANTI, Tania et al. Diesel exhaust particles induce autophagy and citrullination in Normal Human Bronchial Epithelial cells. Cell death \& disease, v. 9, n. 11, p. 1-15, 2018.

${ }^{7}$ GUARIEIRO, L. L. N.; GUARIEIRO, A. L. N. Vehicle Emissions: What Will Change with Use of Biofuel? In: Biofuels - Economy, Environment and Sustainability. [s.I.] InTech, 2013

${ }^{8} \mathrm{KUMAR}, \mathrm{M}$. Vijay; BABU, A. Veeresh; KUMAR, P. Ravi. The impacts on combustion, performance and emissions of biodiesel by using additives in direct injection diesel engine. Alexandria Engineering Journal, v. 57, n. 1, p. 509-516, 2018.

${ }^{9}$ GENG, Peng et al. Effects of alternative fuels on the combustion characteristics and emission products from diesel engines: A review. Renewable and Sustainable Energy Reviews, v. 71, p. 523-534, 2017.

${ }^{10}$ SHARMA, Shubham et al. Effect of restricted emissions during COVID-19 on air quality in India. Science of The Total Environment, v. 728, p. 138878, 2020.

${ }^{11}$ ASGHARIAN, Bahman et al. Computational modeling of nanoscale and microscale particle deposition, retention and dosimetry in the mouse respiratory tract. Inhalation toxicology, v. 26, n. 14, p. 829-842, 2014.

12 MANOJKUMAR, N.; SRIMURUGANANDAM, B.; NAGENDRA, SM Shiva. Application of multiple-path particle dosimetry model for quantifying age specified deposition of particulate matter in human airway. Ecotoxicology and environmental safety, v. 168, p. 241-248, 2019.

${ }^{13}$ GUARIEIRO, Lílian Lefol Nani et al. Assessment of the use of oxygenated fuels on emissions and performance of a diesel engine. Microchemical Journal, v. 117, p. 9499, 2014. 